\title{
Media Pembelajaran Aplikasi Tata Cara Pengurusan Jenazah Berbasis Multimedia
}

\author{
Ulla Delfana Rosiani ${ }^{1}$, Mungki Astiningrum ${ }^{2}$, Faisal Rahutomo ${ }^{3}$, Gunawan Budi Prasetyo ${ }^{4}$, \\ Yushintia Pramitarini ${ }^{5}$ \\ 1,2,3,4,5 Jurusan Teknologi Informasi, Politeknik Negeri Malang \\ e-mail:*11rosiani@polinema.ac.id, ${ }^{2}$ mungki.astingrum@polinema.ac.id, ${ }^{3}$ faisal@polinema.ac.id, \\ ㅂonawan.budi@polinema.ac.id, ${ }^{5}$ yushintia@polinema.ac.id
}

\begin{abstract}
Abstrak
Agama Islam mengajarkan ilmu fiqih dimana dalam kajian tersebut salah satunya membahas tentang pengurusan jenazah. Namun, masyarakat masih membutuhkan pemahaman tentang bagaimana mengurus jenazah di lingkungan daerah sekitar mereka. Untuk membantu memberikan pemahaman tersebut maka akan dilakukan pelatihan tata cara pengurusan jenazah. Pelatihan ini akan menggunakan metode pembelajaran dengan teknik demonstrasi dimana salah satunya adalah dengan menggunakan aplikasi sebagai media pembelajaran berbasis multimedia. Aplikasi tata cara pengurusan jenazah berbasis multimedia dirancang dan dibuat guna untuk menyajikan informasi dengan tampilan yang menarik. Aplikasi dilengkapi dengan suara dan keterangan serta fitur berdasarkan materi persiapan apa saja yang harus disediakan untuk pengurusan hingga menguburkan jenazah. Dengan adanya pelatihan melalui pembuatan aplikasi sebagai media pembelajaran akan dapat meningkatkan pemahaman masyarakat tentang tata cara pengurusan jenazah secara efektif. Kegiatan pengabdian masyarakat ini dapat berjalan lancar, peserta pelatihan mendapatkan pemahaman ilmu tentang tata cara pengurusan jenazah dengan media pembelajaran yang menarik.
\end{abstract}

Kata kunci-Media pembelajaran, pengabdian masyarakat, multimedia, pengurusan jenazah

\section{PENDAHULUAN}

Dalam agama Islam, sesama muslim memiliki kewajiban yang harus dilakukan kepada muslim lainnya yaitu salah satunya adalah dengan membantu mengurus jenazah ketika mereka meninggal. Pada kajian fiqih agama Islam, ada beberapa yang dilakukan langsung di lingkungan masyarakat yaitu fiqih tata cara pengurusan jenazah termasuk pengurusan jenazah [1]. Kewajiban mengurus jenazah termasuk hukum fardhu kifayah dimana artinya jika perbuatan tersebut telah dilakukan oleh satu orang maka gugurlah kewajiban dari orang lainnya namun apabila tidak ada yang melaksanakan hal tersebut sama sekali maka seluruh orang yang ada disekitar jenazah tersebut akan mendapatkan dosa [2]. Dengan adanya media pembelajaran aplikasi tata cara pengurusan jenazah berbasis multimedia dapat membantu masyarakat menambah ilmu serta dapat diterapkan secara langsung di lingkungan masyarakat.

Salah satu usaha yang dilakukan untuk meningkatkan pemahaman masyarakat tentang tata cara pengurusan jenazah yaitu melalui pelatihan kepada masyarakat. Metode pelatihan tata cara pengurusan jenazah ini biasanya merupakan metode konvensional yang masih menggunakan metode ceramah dengan media pembelajaran berupa papan tulis, alat peraga manusia serta membutuhkan alat bantu seperti bahan-bahan yang diperlukan untuk pengurusan jenazah (kain kafan, kapas, dsb.). Metode pembelajaran akan menjadi menarik jika diberi sentuhan teknologi animasi tentang bagaimana tata cara mengurus jenazah mulai dari memandikan, mensholatkan, dan menguburkan sehingga akan menjadi lebih efektif dibandingan dengan metode konvensional.

Objek yang nyata dan menarik akan lebih menarik jika dibandingan dengan ilustrasi saja, karena memang otak manusia lebih tertarik dengan hal yang berupa visual seperti bentuk, gambar dan warna [3]. Dengan perkembangan teknologi informasi pada era sekarang dapat dimanfaatkan dalam menarik minat masyarakat untuk menambah ilmu bagaimana tata cara pengurusan jenazah melalui media visual [4].

Masalah utama yang terkadang dihadapi adalah dengan berkembangnya teknologi, pengetahuan tentang pemanfaatan teknologi informasi masih sangat minim. Banyak teknologi 
informasi yang masih belum maksimal digunakan sebagai media pembelajaran. Oleh karena itu akan dilakukan pemanfaatan teknologi multimedia untuk menunjang proses belajar mengajar tentang tata cara pengurusan jenazah di lingkungan masyarakat pada mitra dan masyarakat sekitar.

\section{METODE}

\subsection{Tahapan Metode Pelaksanaan}

Metode pelaksanaan pada kegiatan pengabdian masyarakat ini dilaksanakan melalui empat tahap, yaitu:

\section{Persiapan}

Tahap ini merupakan tahap awal dalam melaksanakan program PPM. Pada tahap persiapan akan dilakukan survey pendahuluan dengan mitra. Survey ini dilakukan untuk mengetahui permasalahan yang terjadi pada mitra serta mencari solusi dari permasalahan tersebut bersama pihak mitra. Pada tahap ini, akan didata siapa saja yang akan mengikuti pelatihan tentang tata cara pengurusan jenazah. Selain itu, akan dilakukan pemantapan konsep guna untuk menyelaraskan konsep dengan mitra. Ketika konsep sudah disepakati bersama, maka akan dilakukan pembuatan storyboard atau skenario. Jika skenario sudah sesuai barulah dibuat animasi sebagai media pembelajaran tata cara memandikan jenazah.

\section{Pelaksanaan}

Setelah didapatkan informasi serta jumlah peserta yang akan mengikuti pelatihan, maka akan dilaksanakan program pelatihan tata cara pengurusan jenazah dengan metode:

\section{a. Ceramah}

Metode ini sangat bermanfaat sebagai proses alih pengetahuan tentang materi bagaimana tata cara pengurusan jenazah meliputi serangkaian persiapan serta adab yang harus dilakukan ketika pengurusan jenazah. Metode ceramah juga menggunakan media pembelajaran dengan tujuan para peserta pelatihan akan lebih memahami materi karena media yang disajikan berbentuk animasi.

\section{b. Praktek}

Kegiatan praktek dilaksanakan agar peserta pelatihan dapat memahami bagaimana cara membuat storyboard sebelum membuat sebuah aplikasi serta nantinya dapat membuat aplikasi media pembelajaran sebagai sarana belajar. c. Diskusi dan Tanya Jawab

Diskusi dan tanya jawab dilakukan untuk memberikan ruang kepada para peserta pelatihan agar dalam memahami lebih lanjut tentang materi yang disampaikan serta membangun hubungan yang erat antara pelaksana kegiatan Pengabdian Kepada Masyarakat (PPM) dengan mitra.

\section{Evaluasi}

Tahap ini dilakukan untuk mengetahui tingkat pencapaian tujuan pelatihan yang meliputi hal-hal sebagai berikut:

a. Evaluasi terhadap penyerapan materi tentang tata cara pengurusan jenazah yang telah diberikan melalui serangkaian animasi media pembelajaran yang sesuai dengan materi.

b. Evaluasi terhadap penyerapan materi yang telah diberikan melalui serangkaian permasalahan yang dihadapi oleh peserta pelatihan.

4. Pelaporan hasil pengabdian kepada masyarakat Pelaporan hasil PPM ini dilaksanakan setelah semua kegiatan terlaksana sesuai dengan pencapaian tujuan.

\subsection{Desain Storyboard Animasi Media Pembelajaran Tata Cara Pengurusan Jenazah}

Dalam mendesain sebuah animasi media pembelajaran, akan dilakukan pembuatan gambaran kasar dari animasi tersebut. Gambaran yang akan dibuat terdiri beberapa bagian yaitu sebagai berikut:

a. Desain intro

Intro disini berisi tentang pengenalan tentang pelaksana kegiatan pengabdian pada masyarakat dengan mitra. Pada bagian logo akan diberikan logo dari pelaksana PPM serta logo dari mitra. Karakter yang akan digunakan ini akan melambangkan karakter dari pihak mitra yang akan ditambahkan dengan audio agar lebih
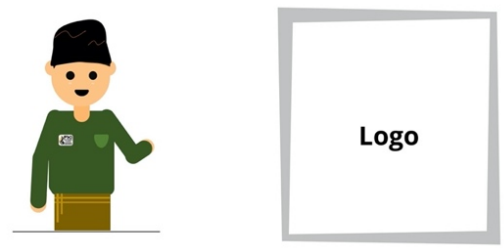

menarik

Gambar 1 Desain intro 
b. Desain Informasi Persyaratan dalam Pengurusan Jenazah

Bagian ini berisi tentang informasi apa saja yang perlu diperhatikan dalam pengurusan jenazah.
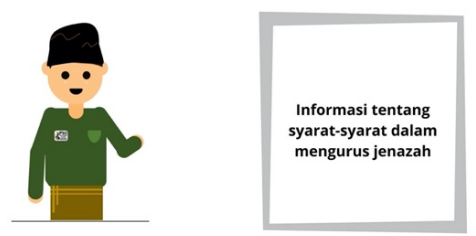

Gambar 2 Desain informasi

c. Desain Interaksi antara aktor 1 dengan aktor 2 untuk berpindah ke bagian berikutnya

Bagian ini berisi tentang interaksi dari 2 aktor yang berbeda dimana aktor 1 adalah aktor yang menyapa dibagian intro sedangkan aktor 2 nantinya akan menjelaskan tentang tata cara pengurusan jenazah di bagian selanjutnya.

Pada bagian ini terdapat komunikasi antara keduanya dan akan mengantarkan para peserta ke bagian inti dari tata cara pengurusan jenazah.

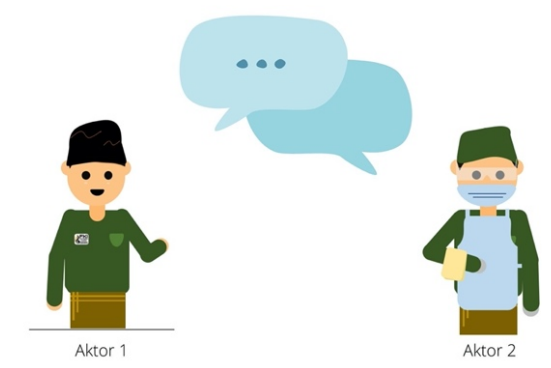

Gambar 3 Desain interaksi 2 aktor

d. Desain Halaman Awal Media Pembelajaran Tata Cara Pengurusan Jenazah

Desain ini menggambarkan halaman awal dari media pembelajaran tentang tata cara pengurusan jenazah. Halaman ini menampilkan judul dan logo dari pelaksana PPM dan mitra pada sudut kanan atas. Selain logo, terdapat pula judul dari media pembelajaran yang akan disajikan pada peserta pelatihan.

\section{Gambar 4 Desain halaman awal dari media pembelajaran}

\section{e. Desain Halaman Konten}

Bagian ini menampilkan tentang informasi yang akan disampaikan kepada peserta mengenai tatacara pengurusan jenazah.
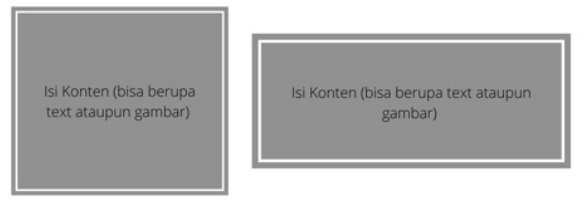

Gambar 5 Desain halaman isi konten yang akan disajikan kepada peserta pelatihan

\section{HASIL DAN PEMBAHASAN}

\subsection{Hasil Implementasi Pembuatan Media Pembelajaran}

Implementasi interface dari aplikasi media pembelajaran yang berhasil dibuat adalah sebagai berikut:

a. Halaman Intro / Pengenalan

Pada halaman ini akan menampilkan perkenalan dari pelaksana PPM dan mitra yang telah bekerja sama.

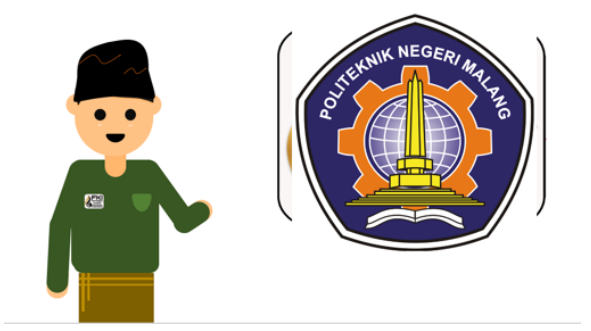

Gambar 6 Halaman intro

b. Halaman Informasi Persyaratan dalam Pengurusan Jenazah

Halaman ini menampilkan informasi syarat-syarat dalam pengurusan jenazah, salah satunya adalah memandikan jenazah.
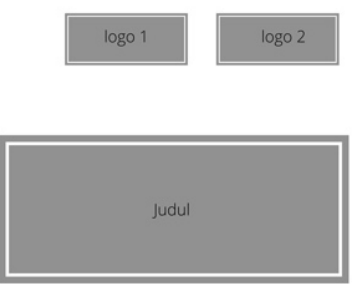


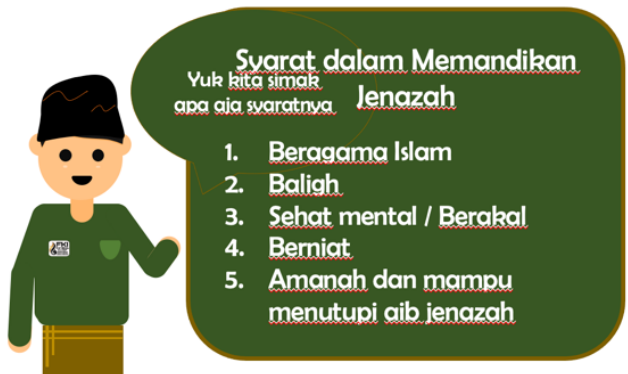

Gambar 7 Salah satu contoh halaman informasi

c. Halaman interaksi antara aktor 1 dengan aktor 2 untuk berpindah ke bagian berikutnya.

Halaman ini menampilkan interaksi dari kedua aktor, salah satu aktornya akan menjelaskan tentang tata cara pengurusan jenazah.

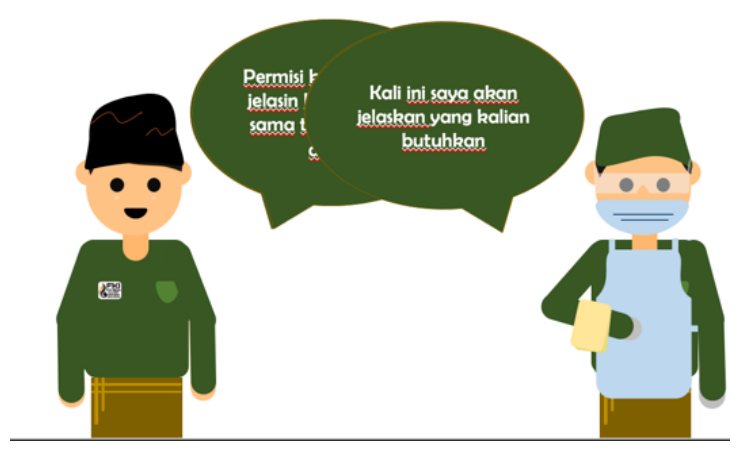

Gambar 8 Interaksi antara 2 aktor

d. Halaman Awal Media Pembelajaran Tata Cara Pengurusan Jenazah

Halaman ini menampilkan tentang judul dari media pembelajaran serta logo dari pihak pelaksana kegiatan pengabdian kepada masyarakat dengan mitra yang telah bekerja sama.

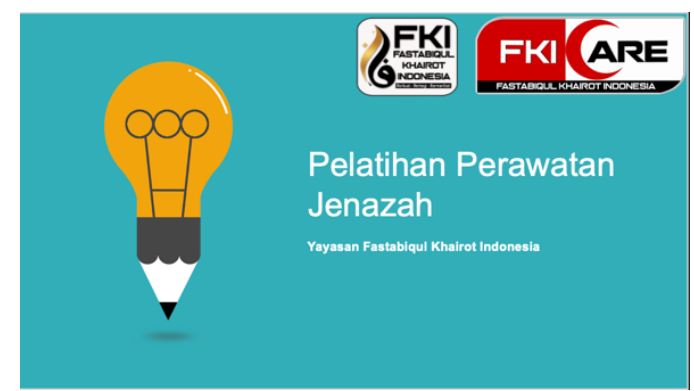

Gambar 9 Halaman awal dari media pembelajaran tata cara pengurusan jenazah

e. Halaman Konten

Halaman konten ini berisi tentang informasi yang akan disajikan kepada peserta pelatihan dimana informasi tersebut mengenai pengurusan jenazah.

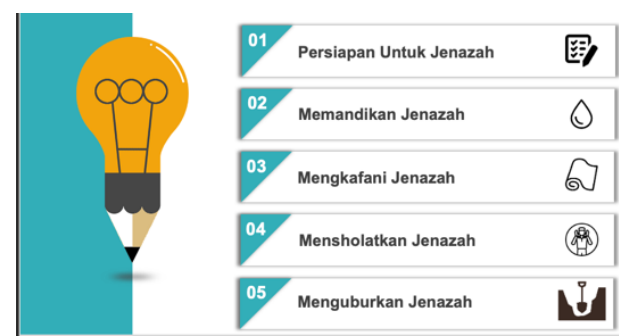

Gambar 10 Salah satu contoh isi konten dari halaman konten

\subsection{Hasil Kegiatan dari Pelaksanaan Pengabdian Kepada Masyarakat Dengan Mitra}

Kegiatan pengabdian yang berupa pelatihan dan pendampingan kepada peserta pelatihan ini dilakukan secara daring dikarenakan masih dalam masa pandemi COVID-19. Kegiatan berlangsung dengan baik diikuti oleh peserta pelatihan dan tim pelaksana. Berikut ini adalah foto kegiatan dari pelaksanaan tersebut:

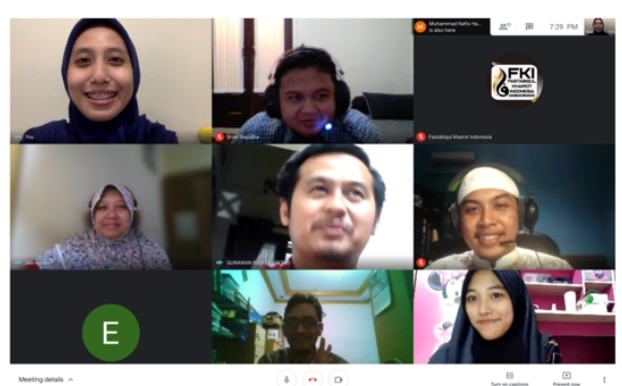

Gambar 11 Kegiatan pelaksanaan PPM dengan mitra

Secara keseluruhan kegiatan berlangsung dengan sukses dan mendapat respon yang positif dari para peserta pelatihan dan mitra. Hal ini dibuktikan dengan kehadiran peserta yang mencapai $90 \%$ serta peserta sangat antusias sekali dalam mengikuti pelatihan ini. Pelaksanaan pelatihan diadakan dalam satu hari secara daring dimana sebelum kegiatan diawali dengan sambutan dari ketua pelaksana dan mitra kemudian baru memasuki acara inti yaitu pengenalan media pembelajaran tentang tata cara pengurusan jenazah.

\subsection{Hasil Pengujian Efektifitas Media Pembelajaran}

Pengujian ini dilakukan untuk mengetahui efektifitasi dari aplikasi media pembelajaran tata cara pengurusan jenazah. Pengujian dilakukan kepada peserta pelatihan yang sudah ditunjuk oleh mitra sebanyak 10 orang dimana terdiri dari pengurus masjid dan warga di daerah perumahan Permata Saxophone, Malang. Pengujian dilakukan dengan mengadakan tanya jawab sebelum (pretest) dan 
sesudah (postest) penggunaan media belajar yang berbentuk visual. Untuk menghitung nilai pretest dan postest digunakan rumus sebagai berikut:

dimana:

$$
p=f / n \times 100
$$

$p=$ persentase

$f=$ frekuensi dari setiap jawaban

$n=$ jumlah koresponden

Tabel 1 rata-rata hasil dari pretest dan postest

\begin{tabular}{|l|c|c|}
\hline \multicolumn{1}{|c|}{ Kegiatan } & Pretest $\mathbf{( \% )}$ & Postest (\%) \\
\hline Memandikan & 37 & 81 \\
\hline Mengkafani & 30 & 77 \\
\hline Menshalati & 49 & 88 \\
\hline Menguburkan & 35 & 76 \\
\hline
\end{tabular}

Dari hasil pengujian melalui pretest (sebelum mengetahui media pembelajaran) dan postest (setelah mengetahui adanya sarana media pembelajaran), maka dapat disimpulkan bahwa terjadi peningkatan pemahaman masyarakat pada tata cara pengurusan jenazah berdasarkan kegiatannya. Kegiatan memandikan jenazah mengalami kenaikan sebesar $44 \%$, kegiatan mengkafani meningkat sebesar $47 \%$, menshalati sebesar 39\%, dan pada kegiatan menguburkan jenazah sebesar $41 \%$. Hasil pengujian selanjutnya adalah untuk mengetahui efektifitas, interaktif dan kemampuan media pembelajaran tata cara pengurusan jenazah dalam menarik minat peserta melalui pemberian kuesioner. Hasil dari penilaian kuesioner yang telah diberikan kepada peserta menghasilkan grafik seperti pada gambar berikut:

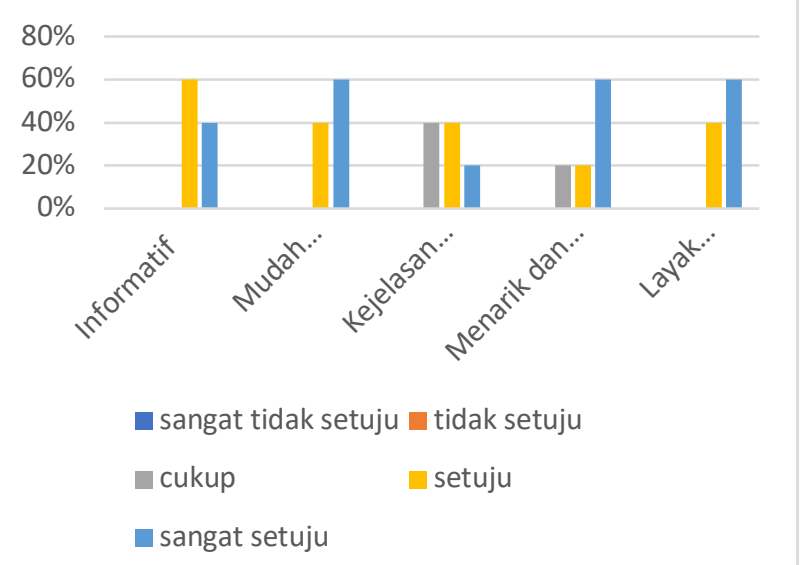

Gambar 12 Grafik persentase kuesioner keefektifan media pembelajaran

Kriteria yang diujikan yaitu informatif, mudah digunakan, kejelasan dari objek, menarik dan interaktif serta kelayakan penggunaan. Hasil dari kuesioner berdasarkan semua kriteria tersebut adalah sebanyak $0 \%$ yang menyatakan sangat tidak setuju, $0 \%$ yang menyatakan tidak setuju, $12 \%$ dari peserta yang menyatakan cukup, $40 \%$ peserta menyatakan setuju dan $48 \%$ peserta yang menyatakan sangat setuju dengan media pembelajaran ini. Oleh karena itu dapat disimpulkan bawah aplikasi media pembelajaran tentang tata cara pengurusan jenazah berbasis multimedia ini sangat efektif, interaktif dan menarik.

\section{KESIMPULAN}

1. Pelatihan tata cara pengurusan jenazah berjalan dengan baik dan seluruh peserta memberikan respon positif dengan adanya media pembelajaran tentang tata cara pengurusan jenazah.

2. Antusiasme peserta ditunjukkan dari tingkat kehadiran sebesar $90 \%$ dan aktif mengikuti kegiatan diskusi dan tanya jawab.

3. Hasil pengujian tingkat keberhasilan pelatihan dari nilai sebelum dan sesudah kegiatan menunjukkan peningkatan pengetahuan yang signifikan dari peserta yaitu kegiatan memandikan jenazah mengalami kenaikan sebesar 44\%, kegiatan mengkafani meningkat sebesar $47 \%$, menshalati sebesar $39 \%$, dan pada kegiatan menguburkan jenazah sebesar $41 \%$.

4. Sebanyak $88 \%$ peserta menyatakan setuju dan sangat setuju terhadap media pembelajaran melalui kriteria informatif, mudah digunakan, kejelasan dari objek, menarik dan interaktif serta kelayakan penggunaan.

\section{SARAN}

Untuk pengembangan dari media pembelajaran ini masih bisa dilanjutkan ke teknologi informasi yang lain contohnya berbasis mobile. Untuk materi dan konten dalam aplikasi media pembelajaran dapat ditambahkan beberapa hadist ataupun dalil Al Qur'an yang berkaitan dengan pengurusan jenazah.

\section{UCAPAN TERIMA KASIH}

Penulis mengucapkan terima kasih kepada Politeknik Negeri Malang yang telah memberikan dukungan moral dan dana terhadap program pengabdian masyarakat ini.

\section{DAFTAR PUSTAKA}

[1] D.M.D. Al-bugha, 2017, Penjelasan Kitab 
Matan Abu Syuja' dengan Dalil Al-Qur'an dan Hadist, Noura Books.

[2] Harahap, B., 2021, Pelatihan Fardhu Kifayah Berbasis Multimedia Pada Serikat Tolong Menolong Istiqomah (STMI), Jurnal Pengabdian Masyarakat Gemilang (JPMG).

[3] Hartanto, B., 2010, Mari Merangsang Potensi Otak, Kompas.com.

[4] Muhajir, 2013, Rancang Bangun Animasi Tajhiz (Pengurusan) Jenazah Menggunakan Macromedia Flash Professional 8. 